\title{
Respons Pertumbuhan Tanaman Kelapa Sawit (Elaeis guineensis) Belum Menghasilkan Umur Dua Tahun terhadap Pemupukan Kalsium
}

\section{Influence of Calcium Fertilizer Application on Growth of Two-year-old Immature Oil Palm}

\author{
Larasati Dena Mardhika, Sudradjat*
}

Departemen Agronomi dan Hortikultura, Fakultas Pertanian, Institut Pertanian Bogor (Bogor Agricultural University), Jl. Meranti, Kampus IPB Darmaga, Bogor 16680, Indonesia Telp.\&Faks.62-251-8629353 e-mail agronipb@indo.net.id

*Penulis untuk korespondensi: sudradjat_ipb@yahoo.com

Disetujui 7 Januari 2015 /Published online 15 Januari 2015

\begin{abstract}
Oil palm is an annual plant which can produce economically to age 25-30 year, it does necessary to maintenance vegetative growth to support generative phase. Liming on acid soils will improve soil fertility by provides essential nutrients. The objective of this experiment was to study response of Ca fertilizer of immature oil palm in age two year. The experiment was conducted from March 2014 to February 2015 at IPB-Cargill Teaching and Research Farm of Oil Palm, Jonggol, Bogor, West Java, Indonesia. The experiment was arranged in randomized block design with one factor and replicated three times. The treatments were four dossages of fertilizer as followed: without Ca as a control (Ca0), $600 \mathrm{~g} \mathrm{Ca}$ plant ${ }^{-1}$ (Ca1), $1200 \mathrm{~g} \mathrm{Ca}$ plant $^{-1}$ (Ca2), $2400 \mathrm{~g} \mathrm{Ca}$ plant $^{-1}$ (Ca3). The results showed that application of Ca fertilizer were not have significant effect on plant height, stem girth, fronds production, frond length, and leaf area. Organic manure by dose $50000 \mathrm{~g}$ per planting hole is sufficient as the first fertilization at the location of this experiment.
\end{abstract}

Keywords: acid soil, liming, soil chemical character, soil nutrient availibility, soil nutrient balance

\section{ABSTRAK}

Kelapa sawit merupakan tanaman tahunan yang dapat berproduksi secara ekonomis sampai dengan umur 25-30 tahun sehingga diperlukan pemeliharaan pertumbuhan vegetatif untuk menunjang umur produksi. Pengapuran pada tanah masam akan memperbaiki kesuburan tanah melalui penyediaan unsur hara. Tujuan penelitian ini adalah mendapatkan respons pertumbuhan vegetatif TBM-2 kelapa sawit terhadap pemberian pupuk Kalsium (Ca). Penelitian dilaksanakan pada Maret 2014 sampai dengan Februari 2015 di Kebun Percobaan dan Penelitian IPB-Cargill, Kecamatan Jonggol, Bogor. Penelitian dilakukan menggunakan rancangan kelompok lengkap teracak (RKLT) satu faktor yaitu dosis pemupukan Ca dengan 4 taraf perlakuan yakni: 1) tanpa Ca (CaO) sebagai kontrol, 2) Ca $600 \mathrm{~g}_{\text {tanaman }^{-1}}$ (Cal), 3) Ca $1200 \mathrm{~g} \mathrm{tanaman}^{-1}$ (Ca2), dan 4) Ca $2400 \mathrm{~g}_{\text {tanaman }^{-1}}$ (Ca3). Hasil penelitian menunjukkan perlakuan tidak memberikan pengaruh nyata pada tinggi tanaman, lingkar batang, jumlah pelepah tumbuh, panjang pelepah daun ke-9, dan luas daun. Pemberian pupuk kandang $50000 \mathrm{~g}$ per lubang tanam tidak memberikan perbedaan pertumbuhan pada setiap perlakuan sehingga menjadi dosis yang cukup sebagai pupuk dasar pada lokasi penelitian dilakukan.

Kata kunci: keseimbangan hara tanah, ketersediaan hara tanah, pengapuran, sifat kimia tanah, tanah masam 


\section{PENDAHULUAN}

Perkebunan kelapa sawit di Indonesia berdasarkan pengusahaannya dikategorikan oleh rakyat, negara, dan swasta. Luas areal perkebunan kelapa sawit di Indonesia pada tahun 2009 yaitu perkebunan rakyat seluas $3061 \quad 413$ ha, perkebunan negara seluas 630512 ha, dan perkebunan swasta seluas 4181369 ha. Areal tersebut terus mengalami peningkatan sehingga pada tahun 2014 perkebunan rakyat diproyeksikan mencapai luas 4166778 ha, perkebunan negara seluas 730891 ha, dan perkebunan swasta seluas 5 688670 ha (Ditjenbun, 2011).

Kelapa sawit merupakan tanaman tahunan yang dapat berproduksi secara ekonomis sampai dengan umur 25-30 tahun, untuk menunjang potensi tersebut pemeliharaan pertumbuhan vegetatif penting dilakukan. Kelapa sawit dapat tumbuh pada tanah dengan beragam karakteristik, seperti histosol, andisol, entisol, inceptisol, dan ultisol (Koedadiri et al., 2007). Perkebunan kelapa sawit pada tahun 2010 tersebar di 22 provinsi (BPS, 2011) dengan tingkat kesesuaian lahan yang beragam. Lahan potensial untuk budidaya kelapa sawit dibatasi oleh faktor lingkungan, sifat fisik, dan sifat kimia tanah. Kondisi yang berbeda dari faktor-faktor tersebut dirumuskan dalam tingkat kesesuaian lahan. Salah satu kriteria tersebut adalah kemasaman tanah (Pahan, 2013). Lahan dengan tingkat kemasaman $(\mathrm{pH})$ rendah cenderung menyebabkan ketersediaan hara mikro dan kekahatan hara makro dan sebaliknya untuk lahan pada kondisi $\mathrm{pH}$ tinggi. Tanaman pada umumnya dapat tumbuh optimal pada $\mathrm{pH}$ netral.

Kesuburan tanah adalah kondisi kemampuan tanah untuk menyediakan unsur hara dalam jumlah cukup dan berimbang sehingga menunjang pertumbuhan dan produksi tanaman sesuai potensinya (Munawar, 2011). Kesuburan tanah dapat diupayakan melalui pemupukan yang berperan dalam penyediaan unsur hara dan ameliorasi tanah. Pemupukan pada perkebunan kelapa sawit dilaksanakan berdasarkan rekomendasi yang bersifat spesifik lokasi (Rahutomo dan Sutarta, 2007). Tanaman akan berproduksi dengan baik pada $\mathrm{pH}$ tanah netral. Pupuk unsur kalsium ( $\mathrm{Ca}$ ) umumnya digunakan untuk pengapuran pada tanah masam. Pengapuran pada tanah masam akan memperbaiki kesuburan tanah melalui penyediaan unsur hara makro dan meningkatkan aktivitas mikroorganisme (Sarief, 1985).

Mineral sumber $\mathrm{Ca}$ antara lain anortit, kalsit, dolomit, dan gipsum (Munawar, 2011). Ca diserap tumbuhan melalui aliran massa (Tisdale et al., 1990) dan bersifat immobile sehingga gejala defisiensi dapat diidentifikasi pada jaringan meristematis yang aktif membelah atau pada jaringan muda. Ca berperan dalam translokasi karbohidrat (Munawar, 2011) dan protein pada jaringan penyimpanan (Millar, 1955). Defisiensi $\mathrm{Ca}$ akan menyebabkan pemendekan, penyempitan, dan nekrosis pada daun (Hartley, 1977); pertumbuhan memendek dan menebal pada akar; penurunan kandungan karbohidrat pada batang dan akar yang akan menghambat fungsi akar (Munawar, 2011) sehingga menyebabkan pertumbuhan abnormal buah dan jaringan penyimpanan (Tisdale et al., 1990 dan Munawar, 2011).

Penelitian ini merupakan penelitian lanjutan yang dilakukan oleh Widodo (April 2013-Maret 2014) pada tanah dengan $\mathrm{pH} 4.2$ yang dikategorikan sangat masam (Pusat Penelitian Tanah 2008). Perlakuan pupuk Ca pada berbagai taraf pada TBM-1 menunjukkan respons tidak nyata terhadap laju pertumbuhan dan fisiologi tanaman (Widodo, 2014). Analisis jaringan daun kelapa sawit TBM-1 memberikan hasil kandungan Ca pada daun kritis, sehingga diperlukan penelitian lanjutan dengan waktu yang lebih lama guna melihat respons pupuk $\mathrm{Ca}$ pada pertumbuhan vegetatif. Tujuan dilakukannya penelitian ini adalah untuk mendapatkan respons pertumbuhan vegetatif TBM-2 kelapa sawit terhadap pupuk $\mathrm{Ca}$ dengan hipotesis terdapat respons peningkatan pertumbuhan vegetatif kelapa sawit TBM-2 terhadap pemberian pupuk $\mathrm{Ca}$ pada taraf tertentu sehingga menghasilkan pertumbuhan vegetatif tertinggi.

\section{BAHAN DAN METODE}

Penelitian dilaksanakan di blok IV, Kebun Pendidikan dan Penelitian Kelapa Sawit IPBCargill yang berlokasi di Kecamatan Jonggol, Kabupaten Bogor Timur. Lokasi terletak pada ketinggian $\pm 115 \mathrm{~m}$ dpl. Penelitian dimulai pada bulan Maret 2014 sampai dengan bulan Februari 2015. Analisis jaringan tanaman dan analisis hara tanah dilaksanakan di laboratorium Pasca Panen Departemen Agronomi dan Hortikultura dan laboratorium Balai Penelitian Tanah, Cimanggu, Bogor.

Bahan tanaman yang digunakan adalah kelapa sawit varietas Tenera Damimas tanaman belum menghasilkan (TBM) umur dua tahun, pupuk dasar yang digunakan terdiri atas urea, SP36, $\mathrm{KCl}$, kieserit, HGF-B, pupuk Ca. Alat yang digunakan terdiri atas peralatan umum pertanian, neraca digital, dan chlorophyll meter SPAD-502 merk Konica Minolta. 
Penelitian dilakukan menggunakan rancangan kelompok lengkap teracak (RKLT) satu faktor yaitu dosis pemupukan kaptan pada TBM-1 dengan 4 taraf perlakuan yakni: 1) tanpa $\mathrm{Ca}(\mathrm{Ca} 0)$ sebagai kontrol, 2) Ca $\left.600 \mathrm{~g}^{\operatorname{tanaman}^{-1}}(\mathrm{Ca} 1), 3\right)$ Ca $1200 \mathrm{~g}_{\operatorname{tanaman}^{-1}}$ (Ca2), dan 4) Ca $2400 \mathrm{~g}$ tanaman $^{-1}$ (Ca3). Setiap taraf percobaan terdiri atas 3 ulangan dan setiap ulangan terdiri atas 5 contoh sehingga keseluruhan penelitian dilakukan menggunakan 60 tanaman. Data dianalisis dengan sidik ragam uji $\mathrm{F}$ pada taraf $\alpha=5 \%$. Perhitungan dan analisis menggunakan program Microsoft Excel dan Minitab.

Aplikasi pemupukan terdiri atas pemupukan saat pembuatan lubang tanam (TBM0 ), perlakuan pemupukan unsur Ca (TBM-1), dan pemupukan dasar (TBM-2). Pemupukan saat TBM 0 berupa pemberian pupuk kandang $50000 \mathrm{~g}$ lubang tanam ${ }^{-1}$. Pemupukan saat TBM-1 dan 2 dilaksanakan dengan cara ditebar di permukaan tanah pada radius $1 \mathrm{~m}$ dari batang. Perlakuan pemupukan unsur Ca dilaksanakan pada tanggal 30 Maret 2013 atau 3 bulan setelah tanam (BST). Pemupukan dasar dilaksanakan dua kali yaitu pada 16 BST (April 2014) dengan dosis urea $500 \mathrm{~g}$ pohon $^{-1}$, SP-36 $250 \mathrm{~g}_{\text {pohon }}{ }^{-1}, \mathrm{KCl} 350 \mathrm{~g}_{\text {pohon }}{ }^{-1}$, dan kieserit $250 \mathrm{~g}$ pohon $^{-1}$ dan pada $24 \mathrm{BST}$ (Desember 2014) dengan dosis urea $500 \mathrm{~g}$ pohon $^{-1}$, SP-36 $250 \mathrm{~g}$ pohon $^{-1}, \mathrm{KCl} 350 \mathrm{~g}_{\text {pohon }}{ }^{-1}$, dan kieserit $250 \mathrm{~g}_{\text {pohon }}{ }^{-1}$, dan HGF $20 \mathrm{~g}_{\text {pohon }}{ }^{-1}$.

Pengamatan meliputi peubah morfologi, luas daun, peubah fisiologi, dan analisis kandungan hara jaringan dan tanah. Peubah morfologi terdiri atas: tinggi tanaman $(\mathrm{cm})$, lingkar batang $(\mathrm{cm})$, panjang pelepah daun atau rachis ke-9 (cm), panjang dan lebar anak daun pelepah ke-9 $(\mathrm{cm})$, dan jumlah leaflet (anak daun) pelepah ke-9. Luas daun dihitung mengacu kepada rumus oleh Sutarta et al. $(2007) ; \mathrm{LD}=(((\Sigma(\mathrm{p} \times 1)): 6) \times 2 \mathrm{n} \times \mathrm{k})$. Dengan LD = luas daun; $p=$ panjang anak daun ke-9; 1 = lebar anak daun ke-9; $\mathrm{n}=$ jumlah anak daun; dan $\mathrm{k}=$ konstanta (untuk TBM senilai 0.57). Peubah fisiologi terdiri atas dua parameter yaitu kandungan klorofil dan analisis jaringan daun. Kandungan klorofil daun diukur menggunakan alat bantu SPAD-502 merk Konica Minolta. Pengukuran dilakukan pada 19, 23, dan 26 BST
(Juli dan November 2014 serta Februari 2015). Kadar klorofil diketahui dengan menggunakan rumus (Farhana et al., 2007) $\mathrm{Y}=0.0007 \times$ 0.0059 dengan $\mathrm{Y}=$ kandungan klorofil dan $x=$ hasil pengukuran menggunakan SPAD-502.

Analisis hara jaringan dilakukan satu kali pada akhir penelitian dengan mengambil contoh anak daun pelepah ke-9 sebanyak 3 pohon yang dipilih secara acak untuk setiap kombinasi perlakuan dan ulangan sehingga diperoleh 12 sampel daun. Anak daun dipotong menjadi 3 bagian dan diambil sepanjang $\pm 20-30 \mathrm{~cm}$ bagian tengahnya, dipisahkan dari tulang daunnya, dioven pada suhu sekitar $60-70{ }^{\circ} \mathrm{C}$, dan dianalisis kandungan hara Nitrogen (N), Fosfor (P), Kalium (K), dan Ca. Sedangkan analisis hara tanah dilakukan dengan menggambil contoh tanah terganggu pada 27 BST (Maret 2015) dengan metode komposit 3 pohon yang dipilih secara acak untuk setiap kombinasi perlakuan dan ulangan sehingga diperoleh 12 sampel tanah komposit. Sampel tanah diambil pada kedalaman $20 \mathrm{~cm}$ di bawah permukaan piringan dengan bobot $2000 \mathrm{~g}$. Contoh tanah dikeringudarakan, dihaluskan, dan diayak menggunakan saringan. Contoh tanah kemudian dianalisis di laboratorium Balai Penelitian Tanah, Cimanggu, Bogor. Analisis meliputi unsur hara $\mathrm{N}, \mathrm{P}, \mathrm{K}, \mathrm{Ca}$, dan Magnesium $(\mathrm{Mg})$.

\section{HASIL DAN PEMBAHASAN}

Hasil analisis terhadap beberapa sifat kimia pada sampel tanah awal yang diperoleh dibandingkan dengan indikator (Pusat Penelitian Tanah, 2008) sehingga diperoleh $\mathrm{pH}$ senilai 4.2 yang tergolong sangat masam; $\mathrm{N} 0.13 \%$ yang tergolong rendah; $\mathrm{P}$ tersedia $2.1 \mathrm{ppm}$ yang tergolong sangat rendah; $\mathrm{K} 0.13$ me $100 \mathrm{~g}^{-1}$ yang tergolong rendah; $\mathrm{Ca} 7.66 \mathrm{me} 100 \mathrm{~g}^{-1}$ yang tergolong sedang; dan $\mathrm{Mg} 1.88 \mathrm{me} 100 \mathrm{~g}^{-1}$ yang tergolong sedang. Kapasitas Tukar Kation (KTK) tanah $26.86 \%$ yang tergolong tinggi dengan kejenuhan basa $37 \%$ yang tergolong sedang. Laju pertumbuhan karakter morfologi dari setiap perlakuan tertera pada Tabel 1.

Tabel 1. Laju pertumbuhan tinggi tanaman, lingkar batang, jumlah pelepah, panjang pelepah kesembilan, dan luas daun TBM-2 kelapa sawit

\begin{tabular}{clcccc}
\hline \multirow{2}{*}{ Dosis $\left(\mathrm{g} \mathrm{tanaman}^{-1}\right)$} & \multicolumn{5}{c}{ Laju pertumbuhan $\left(\right.$ bulan $\left.^{-1}\right)$} \\
\cline { 2 - 6 } & TT $(\mathrm{cm})$ & LB $(\mathrm{cm})$ & JP $($ pelepah $)$ & PP $(\mathrm{cm})$ & LD $\left(\mathrm{cm}^{2}\right)$ \\
\hline 0 & 15.68 & 2.48 & 2.84 & 10.75 & 217.84 \\
600 & 18.35 & 2.22 & 2.81 & 12.09 & 220.51 \\
1200 & 12.27 & 2.51 & 2.78 & 10.97 & 227.89 \\
2400 & 15.14 & 2.19 & 2.86 & 14.25 & 279.79 \\
\hline
\end{tabular}

Keterangan: TT: tinggi tanaman, LB: lingkar batang, JP: jumlah pelepah, PP: panjang pelepah kesembilan, LD: luas daun pelepah kesembilan 
Respons Peubah Morfologi

\section{Tinggi Tanaman}

Tinggi TBM-2 kelapa sawit menunjukkan hasil yang tidak berpengaruh nyata terhadap perlakuan pemupukan unsur Ca pada 15-26 BST. Rata-rata tinggi tanaman ditunjukkan pada Tabel 2. Perlakuan Ca $600 \mathrm{~g}_{\text {tanaman }^{-1}}$ pada 17-26 BST menghasilkan pertumbuhan yang secara konsisten selalu tertinggi daripada perlakuan lainnya. Kelapa sawit diukur tingginya berdasarkan letak ujung daun tombak, yaitu pelepah termuda yang telah terbentuk sempurna, tampak melalui anak daun telah membuka. Pertumbuhan tidak terbatas (indeterminate growth) batang tumbuhan disebabkan aktivitas meristem apikal yang terletak pada ujung pucuk tunas. Meristem disusun oleh sel inisial yang berperan membentuk sel baru serta sel derivatif yang akan terspesialisasi menjadi jaringan tertentu (Campbell et al., 2008). Laju pertumbuhan tinggi pada penelitian sebelumnya $7.4 \mathrm{~cm} \mathrm{bulan}^{-1}$ meningkat menjadi $15.36 \mathrm{~cm}_{\text {bulan }}{ }^{-1}$ sedangkan pertumbuhan lingkar batang $4.8 \mathrm{~cm}$ bulan $^{-1}$ menurun menjadi $2.35 \mathrm{~cm}^{b^{-1}}$, hal $^{-1}$ ini sesuai dengan Pahan (2013) yang menyatakan umur 1-2 tahun pertumbuhan cenderung pada pembesaran pangkal dilanjutkan pertumbuhan setelahnya cenderung kepada pertambahan tinggi yang lebih cepat.

Tabel 2. Tinggi TBM-2 kelapa sawit pada berbagai taraf pemupukan unsur Ca

\begin{tabular}{|c|c|c|c|c|c|}
\hline \multirow{2}{*}{ Dosis Ca $\left(\mathrm{g}_{\text {tanaman }}{ }^{-1}\right)$} & \multicolumn{5}{|c|}{ Tinggi tanaman $(\mathrm{cm})$} \\
\hline & $15 \mathrm{BST}$ & $18 \mathrm{BST}$ & $21 \mathrm{BST}$ & $24 \mathrm{BST}$ & $26 \mathrm{BST}$ \\
\hline 0 & 227.00 & 299.28 & 356.80 & 381.07 & 415.12 \\
\hline 600 & 213.13 & 321.95 & 372.77 & 393.13 & 433.27 \\
\hline 1200 & 246.20 & 296.13 & 346.37 & 372.93 & 393.40 \\
\hline 2400 & 230.07 & 296.77 & 363.85 & 389.07 & 411.73 \\
\hline $\mathrm{CV}(\%)$ & 9.91 & 8.34 & 5.78 & 5.18 & 7.55 \\
\hline $\operatorname{Pr}$ & 0.49 & 0.69 & 0.51 & 0.72 & 0.61 \\
\hline Notasi & tn & tn & tn & tn & tn \\
\hline
\end{tabular}

Keterangan: tn: tidak berbeda nyata pada taraf 5\%, BST: bulan setelah tanam, Pr: probabilitas, CV: Coefficient of Variance

\section{Lingkar Batang}

Lingkar batang TBM-2 kelapa sawit menunjukkan hasil yang tidak berpengaruh nyata terhadap perlakuan pemupukan unsur Ca pada 1526 BST. Rata-rata lingkar batang ditunjukkan pada Tabel 3. Perlakuan Ca $600 \mathrm{~g} \mathrm{tanaman}^{-1}$ pada $15-23$ BST menghasilkan pertumbuhan yang secara konsisten selalu tertinggi daripada perlakuan lainnya. Ketiak pelepah yang menempel pada batang kelapa sawit merupakan letak bunga sebagai bakal tandan buah segar (TBS). Sukmawan (2014) menyatakan lingkar batang yang diharapkan adalah yang berukuran besar sehingga akan terdapat lebih banyak bakal TBS. Pertambahan ukuran lingkar batang yang optimal dapat diupayakan melalui ketersediaan unsur N, P, dan $\mathrm{K}$ yang terjadi dalam waktu bersamaan. Ketersediaan hara jaringan yang menunjukkan unsur $\mathrm{K}$ optimum dibatasi oleh unsur $\mathrm{N}$ dan $\mathrm{P}$ dalam keadaan defisiensi.

Tabel 3. Lingkar batang TBM-2 kelapa sawit pada berbagai taraf pemupukan unsur $\mathrm{Ca}$

\begin{tabular}{|c|c|c|c|c|c|}
\hline \multirow{2}{*}{ Dosis Ca $\left(\mathrm{g} \mathrm{tanaman}^{-1}\right)$} & \multicolumn{5}{|c|}{ Lingkar batang $(\mathrm{cm})$} \\
\hline & $15 \mathrm{BST}$ & $18 \mathrm{BST}$ & $21 \mathrm{BST}$ & $24 \mathrm{BST}$ & 26 BST \\
\hline 0 & 76.48 & 84.57 & 91.96 & 100.85 & 106.23 \\
\hline 600 & 79.47 & 89.08 & 97.52 & 103.47 & 106.07 \\
\hline 1200 & 76.33 & 87.43 & 96.46 & 103.73 & 106.44 \\
\hline 2400 & 78.93 & 85.97 & 94.16 & 102.37 & 105.20 \\
\hline CV (\%) & 5.47 & 4.24 & 3.85 & 3.56 & 3.35 \\
\hline Pr & 0.72 & 0.51 & 0.26 & 0.81 & 0.96 \\
\hline Notasi & tn & tn & $\mathrm{t}_{1}$ & tn & tn \\
\hline
\end{tabular}

Keterangan: tn: tidak berbeda nyata pada taraf 5\%, BST: bulan setelah tanam, Pr: probabilitas, CV: Coefficient of Variance

\section{Jumlah Pelepah dan Panjang Pelepah Daun} Kesembilan

Jumlah pelepah TBM-2 kelapa sawit menunjukkan hasil yang tidak berpengaruh nyata terhadap pemupukan unsur Ca pada 15-26 BST. Rata-rata jumlah pelepah ditunjukkan pada Tabel 4. Perlakuan Ca $600 \mathrm{~g}_{\text {tanaman }}^{-1}$ pada 15-17 BST dan 21-24 BST menghasilkan pertumbuhan yang secara konsisten selalu tertinggi daripada perlakuan lainnya. Jumlah pelepah berkaitan dengan potensi produksi TBS, semakin banyak pelepah akan meningkatkan produktivitas TBS. Produksi pelepah akan semakin banyak seiring meningkatnya $\mathrm{CH}$, pada TBM-1 peningkatan $\mathrm{CH}$ 
dapat menyebabkan produksi 2.5 pelepah pbulan $^{-1}$ (Sudradjat et al., 2014).

Panjang pelepah kesembilan TBM-2 kelapa sawit menunjukkan hasil yang tidak berpengaruh nyata terhadap perlakuan pemupukan unsur Ca pada 15-26 BST. Rata-rata panjang pelepah kesembilan ditunjukkan pada Tabel 5. Perlakuan Ca $600 \mathrm{~g}^{\text {tanaman }^{-1}}$ pada 17-24 BST menghasilkan pertumbuhan yang secara konsisten selalu tertinggi daripada perlakuan lainnya. Panjang pelepah kesembilan menunjukkan luasan permukaan daun akan menangkap radiasi matahari sebagai bahan fotosintat untuk menunjang pertumbuhan dan produksi. Pelepah selama fase TBM dapat bertambah sebanyak 1-3 pelepah setiap bulan sampai mencapai jumlah optimum. Jika tanaman telah memasuki fase tanaman menghasilkan (TM) maka diperlukan pengelolaan tajuk melalui penunasan, sehingga memungkinkan radiasi matahari yang diterima dapat termanfaatkan sebagai bahan fotosintesis tanaman (Pahan, 2013).

Tabel 4. Jumlah pelepah TBM-2 kelapa sawit pada berbagai taraf pemupukan unsur Ca

\begin{tabular}{|c|c|c|c|c|c|}
\hline \multirow{2}{*}{ Dosis Ca $\left(\mathrm{g}_{\text {tanaman }}{ }^{-1}\right)$} & \multicolumn{5}{|c|}{ Jumlah pelepah } \\
\hline & $15 \mathrm{BST}$ & $18 \mathrm{BST}$ & $21 \mathrm{BST}$ & $24 \mathrm{BST}$ & $26 \mathrm{BST}$ \\
\hline 0 & 2.62 & 13.00 & 23.17 & 30.47 & 36.68 \\
\hline 600 & 2.60 & 12.87 & 22.47 & 30.07 & 36.27 \\
\hline 1200 & 2.47 & 12.60 & 22.53 & 29.87 & 35.80 \\
\hline 2400 & 2.47 & 13.07 & 23.07 & 30.73 & 36.73 \\
\hline $\mathrm{CV}(\%)$ & 12.09 & 4.16 & 3.62 & 3.78 & 4.42 \\
\hline $\operatorname{Pr}$ & 0.812 & 0.749 & 0.56 & 0.79 & 0.87 \\
\hline Notasi & tn & tn & tn & tn & tn \\
\hline
\end{tabular}

Keterangan: tn: tidak berbeda nyata pada taraf 5\%, BST: bulan setelah tanam, Pr: probabilitas, CV: Coefficient of Variance

Tabel 5. Panjang pelepah kesembilan TBM-2 kelapa sawit pada berbagai taraf pemupukan unsur Ca

\begin{tabular}{|c|c|c|c|c|c|}
\hline \multirow{2}{*}{ Dosis Ca $\left(\mathrm{g} \mathrm{tanaman}^{-1}\right)$} & \multicolumn{5}{|c|}{ Jumlah pelepah } \\
\hline & $15 \mathrm{BST}$ & $18 \mathrm{BST}$ & $21 \mathrm{BST}$ & $24 \mathrm{BST}$ & $26 \mathrm{BST}$ \\
\hline 0 & 160.58 & 201.75 & 258.40 & 279.80 & 289.60 \\
\hline 600 & 165.57 & 226.90 & 272.13 & 296.87 & 310.67 \\
\hline 1200 & 152.53 & 213.41 & 252.09 & 270.27 & 284.20 \\
\hline 2400 & 150.37 & 210.37 & 254.13 & 283.33 & 321.33 \\
\hline $\mathrm{CV}(\%)$ & 7.97 & 7.84 & 6.27 & 6.68 & 9.27 \\
\hline $\operatorname{Pr}$ & 0.56 & 0.46 & 0.60 & 0.52 & 0.44 \\
\hline Notasi & tn & $\operatorname{tn}$ & tn & $\operatorname{tn}$ & tn \\
\hline
\end{tabular}

Keterangan: tn: tidak berbeda nyata pada taraf 5\%, BST: bulan setelah tanam, Pr: probabilitas, CV: Coefficient of Variance

Luas Daun Pelepah Kesembilan

Luas daun TBM-2 kelapa sawit menunjukkan hasil yang tidak berpengaruh nyata terhadap perlakuan pemupukan unsur Ca pada 15-
26 BST. Rata-rata luas ditunjukkan pada Tabel 6. Perlakuan Ca $600 \mathrm{~g}_{\text {tanaman }}^{-1}$ pada 19-24 BST menghasilkan pertumbuhan yang secara konsisten selalu tertinggi daripada perlakuan lainnya.

Tabel 6. Luas daun pelepah kesembilan TBM-2 kelapa sawit pada berbagai taraf pemupukan unsur Ca

\begin{tabular}{|c|c|c|c|c|c|}
\hline \multirow{2}{*}{ Dosis Ca $\left(\mathrm{g}_{\text {tanaman }}{ }^{-1}\right)$} & \multicolumn{5}{|c|}{ Luas daun $\left(\mathrm{cm}^{2}\right)$} \\
\hline & $15 \mathrm{BST}$ & $18 \mathrm{BST}$ & $21 \mathrm{BST}$ & $24 \mathrm{BST}$ & $26 \mathrm{BST}$ \\
\hline 0 & 3644.75 & 5190.63 & 6924.92 & 5832.35 & 6258.81 \\
\hline 600 & 3537.52 & 4815.95 & 7483.21 & 5956.48 & 6183.62 \\
\hline 1200 & 3582.00 & 4741.12 & 6366.42 & 5485.55 & 6316.68 \\
\hline 2400 & 3260.94 & 3950.89 & 7131.54 & 5903.6 & 6618.42 \\
\hline $\mathrm{CV}(\%)$ & 24.17 & 17.36 & 11.59 & 11.03 & 18.88 \\
\hline $\operatorname{Pr}$ & 0.91 & 0.43 & 0.552 & 0.887 & 0.961 \\
\hline Notasi & tn & tn & tn & tn & tn \\
\hline
\end{tabular}

Keterangan: tn: tidak berbeda nyata pada taraf 5\%, BST: bulan setelah tanam, Pr: probabilitas, CV: Coefficient of Variance

Luas daun menunjukkan penurunan pada pengamatan dari umur 21 BST ke 24 BST. Penurunan luas daun diduga merupakan respons cekaman kekeringan berupa $\mathrm{CH}$ rendah. Luas daun yang diamati pada $18,21,24$, dan 26 BST merupakan respons akumulasi $\mathrm{CH}$ pada bulan sebelum pengamatan. $\mathrm{CH}$ pada $15-17$ BST adalah $1023.5 \mathrm{~mm}$, pada $18-20$ BST $502 \mathrm{~mm}$, pada $21-$ 
23 BST $314 \mathrm{~mm}$, pada 24-25 BST $318 \mathrm{~mm}$, sehingga penurunan $\mathrm{CH}$ terjadi di antara pengamatan 21 dan $24 \mathrm{BST}$, yang menyebabkan penurunan luas daun pada seluruh perlakuan. Respons tanaman terhadap kekeringan ditujukan untuk menekan kehilangan air (Mathius et al., 2001), dapat berupa penyempitan daun (Setiawan et al., 2013).

\section{Respons Peubah Fisiologi}

\section{Kandungan Klorofil}

Kandungan klorofil TBM-2 kelapa sawit menunjukkan hasil yang tidak berpengaruh nyata terhadap perlakuan pemupukan unsur Ca pada 15$26 \mathrm{BST}$, hal ini sesuai dengan pemberian pupuk $\mathrm{Ca}$ pada bibit kelapa sawit yang tidak berpengaruh nyata, sedangkan pemberian pupuk $\mathrm{Mg}$ berpengaruh nyata pada kandungan klorofil karena berperan sebagai penyusun klorofil (Ningsih, 2013). Kandungan klorofil ditunjukkan pada Tabel 7. Menurut Ai dan Banyo (2011) konsentrasi klorofil pada daun dapat menjadi indikator cekaman kekeringan pada tumbuhan. Unsur penyusun klorofil adalah Magnesium $(\mathrm{Mg})$ yang diserap tanaman melalui aliran masa dalam bentuk larutan tanah ion $\mathrm{Mg}^{2+}$ (Munawar, 2011).

Tabel 7. Kandungan klorofil TBM-2 kelapa sawit pada berbagai taraf pemupukan unsur $\mathrm{Ca}$

\begin{tabular}{cccc}
\hline \multirow{2}{*}{$\begin{array}{c}\text { Dosis Ca } \\
\left(\mathrm{g} \mathrm{tanaman}^{-1}\right)\end{array}$} & \multicolumn{3}{c}{ Kandungan Klorofil $\left(\mathrm{mg} \mathrm{cm}^{-2}\right)$} \\
\cline { 2 - 4 } & 19 BST & 23 BST & 26 BST \\
\hline 0 & 0.0565 & 0.0037 & 0.0368 \\
600 & 0.0566 & 0.0369 & 0.0307 \\
1200 & 0.0577 & 0.0356 & 0.0377 \\
2400 & 0.0570 & 0.0363 & 0.0383 \\
\hline $\mathrm{CV}(\%)$ & 3.85 & 6.54 & 17.26 \\
\hline Pr & 0.740 & 0.758 & 0.060 \\
\hline Notasi & tn & tn & tn \\
\hline
\end{tabular}

Keterangan: tn: tidak berbeda nyata pada taraf 5\%, BST: bulan setelah tanam, Pr: probabilitas, CV: Coefficient of Variance

Perlakuan 0 g $\operatorname{tanaman}^{-1}$ pada 23 BST menunjukkan kandungan klorofil yang menurun drastis (0.0037) dan lebih rendah daripada perlakuan lain, sebagai respons $\mathrm{CH}$ rendah pada 19-22 BST (284 mm) sedangkan $\mathrm{CH}$ pada $15-19$ BST mencapai $1273.5 \mathrm{~mm}$ dan pada 23-25 BST $844 \mathrm{~mm}$. Tanah di lokasi penelitian memiliki $\mathrm{pH}$ 4.2 (sangat masam) bertekstur liat sehingga diduga pertumbuhan tanaman merupakan respons atas cekaman kekeringan dan tanah masam. Ca berperan membantu mengatur respons tanaman terhadap lingkungan (Munawar, 2011). Tanah masam dan liat menyebabkan kemampuan akar menyerap $\mathrm{Ca}^{2}$ digantikan dengan kompetitor Aluminium (Al) sehingga pertumbuhan akar terhambat (Sopandie, 2014) berimplikasi pada serapan $\mathrm{Mg}^{2+}$ rendah dan menghambat pembentukan klorofil.

\section{Kandungan Hara Jaringan}

Menurut Uexkull et al. (1992), tanaman kelapa sawit muda (kurang dari 6 tahun) memiliki tingkat defisiensi hara pada daun apabila kurang dari $2.5 \% \mathrm{~N}$, kurang dari $0.15 \% \mathrm{P}$, kurang dari $1.00 \% \mathrm{~K}$, dan kurang dari $0.30 \% \mathrm{Ca}$. Hasil pengamatan rata-rata kandungan hara jaringan tertera pada Tabel 8. Berdasarkan hasil analisis kandungan hara pada 26 BST maka diperoleh rataan persentase $\mathrm{N}(1.75 \%)$ dan $\mathrm{P}(0.14 \%)$ pada kondisi defisiensi. Hal tersebut diduga disebabkan ketersediaan unsur $\mathrm{N}, \mathrm{P}$, dan $\mathrm{K}$ yang tidak seimbang serta sifat fisik dan kimia tanah yang menyebabkan kondisi tidak tersedianya hara bagi tanaman. Defisiensi N yang terjadi dapat disebabkan pembatasan oleh $\mathrm{Ca}$ atau pelindian. Unsur $\mathrm{Ca}$ akan membatasi penyerapan $\mathrm{N}$ dan meningkatkan $\mathrm{K}, \mathrm{N}$ yang berlebih akan menyebabkan tertundanya kemasakan buah (Munawar, 2011) sementara tanaman pada fase vegetatif umumnya mengurangi hara pada daun untuk dialokasikan pada pembentukan buah. Kehilangan unsur $\mathrm{N}$ dapat disebabkan pelindian akibat terjadinya $\mathrm{CH}$ bulan basah (BB) berturutturut pada November-Februari.

Unsur K (1.24\%) berada pada kondisi optimum $(1.10-1.30 \%)$ dan $\mathrm{Ca}(0.85 \%)$ pada kondisi menuju luxury (berlebihan) yaitu disebabkan nilai rataan yang berada pada rentang kondisi optimum $(0.50-0.70 \%)$ dan kondisi berlebih (lebih dari 1.00\%). Ca pada setiap perlakuan menunjukkan peningkatan daripada kondisi sebelum diberikannya perlakuan, yaitu perlakuan $0 \mathrm{~g} \mathrm{tanaman}{ }^{-1} 0.31 \%$ menjadi $0.83 \%$, perlakuan $600 \mathrm{~g} \operatorname{tanaman}^{-1}$ dari $0.29 \%$ menjadi $0.84 \%$, perlakuan $1200 \mathrm{~g}^{-1} \operatorname{tanaman}^{-1}$ dari $0.31 \%$ menjadi $0.85 \%$, perlakuan $2400 \mathrm{~g}^{-1} \operatorname{tanaman}^{-1}$ dari $0.31 \%$ menjadi $0.87 \%$. Peningkatan kandungan $\mathrm{Ca}$ pada TBM-2 dibandingkan TBM-1 diduga disebabkan ketersediaan air yang lebih banyak dengan 9 BB dan tanpa diselingi bulan kering (BK) seperti yang terjadi saat TBM-1. Penyerapan $\mathrm{Ca}^{2+}$ meningkat seiring semakin banyak tanaman menyerap air. 
Tabel 8. Rata-rata kandungan hara jaringan daun pada berbagai taraf pemupukan unsur $\mathrm{Ca}$

\begin{tabular}{|c|c|c|c|c|}
\hline Dosis Ca $\left(\mathrm{g}^{2} \operatorname{tanaman}^{-1}\right)$ & $\mathrm{N}$ total $(\%)$ & $\mathrm{P}$ total $(\%)$ & $\mathrm{K}$ total $(\%)$ & Ca total $(\%)$ \\
\hline 0 & 1.78 & 0.15 & 1.22 & 0.83 \\
\hline 600 & 1.76 & 0.14 & 1.22 & 0.84 \\
\hline 1200 & 1.75 & 0.14 & 1.25 & 0.85 \\
\hline 2400 & 1.71 & 0.14 & 1.26 & 0.87 \\
\hline Rata-rata & 1.75 & 0.14 & 1.24 & 0.85 \\
\hline $\mathrm{CV}(\%)$ & 7.47 & 8.81 & 6.83 & 3.99 \\
\hline $\operatorname{Pr}$ & 0.93 & 0.18 & 0.40 & 0.07 \\
\hline Notasi & tn & tn & tn & tn \\
\hline
\end{tabular}

Keterangan: tn: tidak berbeda nyata pada taraf 5\%, BST: bulan setelah tanam, Pr: probabilitas, CV: Coefficient of Variance

\section{Kandungan Hara Tanah}

Hasil pengamatan kandungan hara tanah tertera pada Tabel 9. Kandungan hara rataan unsur C yaitu $2.06 \%$ menunjukkan hasil pada kelas sedang (2-3\%). Rataan C menunjukkan ketersediaan yang meningkat dibandingkan dengan sebelum diberikannya perlakuan (1.41\%). Perlakuan dosis 0 dan $240 \mathrm{~g} \operatorname{tanaman}^{-1}$ mampu memberikan ketersediaan $\mathrm{C}$ pada kelas sedang sedangkan dosis 60 dan $120 \mathrm{~g}$ tanaman $^{-1}$ menunjukkan kandungan $\mathrm{C}$ pada kelas rendah (1$2 \%)$.

Rataan kandungan unsur $\mathrm{N}$ yaitu $0.21 \%$ menunjukkan hasil pada kelas sedang $(0.21-0.5 \%)$ seperti yang terjadi pada perlakuan dosis 0,1200 , dan $2400 \mathrm{~g}$ tanaman $^{-1}$ namun dosis $60 \mathrm{~g} \mathrm{tanaman}^{-1}$ menunjukkan kandungan $\mathrm{N}$ pada kelas rendah (0.1-0.2\%). Ketersediaan N menunjukkan peningkatan daripada sebelum perlakuan yaitu $0.13 \%$. Berdasarkan kandungan $\mathrm{C}$ dan $\mathrm{N}$ maka diperoleh rasio rata-rata $(10.08 \%)$ tergolong kelas rendah (5-10). Rataan kandungan unsur $\mathrm{Ca}$ total $0.14 \%$ (3.59 me $100 \mathrm{~g}^{-1}$ ) terkategori rendah dan mengalami penurunan dari sebelum perlakuan
(7.66 me $100 \mathrm{~g}^{-1}$ ), rataan unsur $\mathrm{Mg}$ total $0.25 \%$ (6.41 me $100 \mathrm{~g}^{-1}$ ) yang terkategori tinggi dan mengalami peningkatan dari sebelum perlakuan

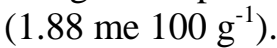

Kandungan hara dipengaruhi oleh sifat fisik, kimia, dan biologi tanah. Analisis terhadap tekstur tanah tiga fraksi menunjukkan hasil $16 \%$ pasir, 36\% debu, dan $48 \%$ liat, berdasarkan segitiga tekstur maka tanah di lokasi penelitian tergolong tanah liat. Nilai $\mathrm{pH}$ tanah (4.2) yang tergolong sangat masam menyebabkan unsur Aluminium ( $\mathrm{Al}$ ) berpotensi tersedia dalam bentuk kation yang mudah teradsopsi oleh larutan tanah. Kondisi tersebut menghasilkan reaksi yang akan meningkatkan ion $\mathrm{H}^{+}$sehingga menurunkan $\mathrm{pH}$ tanah. Hal tersebut ditambah dengan aktivitas mikroorganisme yang menghasilkan asam di dalam tanah, yang terjadi lebih tinggi pada musim panas (Buckman dan Brady, 1982). Perbaikan sifat tanah dapat dicapai melalui pemupukan bahan organik sebagai pembenah sifat biologi. Terhadap TBM-1 kelapa sawit, diketahui pemberian pupuk organik dan NPK majemuk dapat meningkatkan pertumbuhan vegetatif tanaman (Siallagan et al., 2014).

Tabel 9. Rata-rata kandungan hara tanah setiap perlakuan pemupukan unsur $\mathrm{Ca}$

\begin{tabular}{lccccccc}
\hline Dosis Ca $(\mathrm{gtanaman}$ & -1 & $\mathrm{C}$ organik \\
$(\%)$ & $\mathrm{N}(\%)$ & $\mathrm{C} / \mathrm{N}$ & P total $(\%)$ & $\mathrm{K}$ total $(\%)$ & Ca total $(\%)$ & $\mathrm{Mg}$ total $(\%)$ \\
\hline 0 & 2.15 & 0.21 & 10.33 & 0.23 & 0.20 & 0.15 & 0.27 \\
600 & 1.99 & 0.19 & 10.67 & 0.26 & 0.20 & 0.14 & 0.26 \\
1200 & 1.96 & 0.22 & 9.00 & 0.19 & 0.16 & 0.15 & 0.25 \\
2400 & 2.13 & 0.21 & 10.33 & 0.18 & 0.17 & 0.11 & 0.23 \\
\hline Rata-rata & 2.06 & 0.21 & 10.08 & 0.22 & 0.18 & 0.14 & 0.25 \\
\hline CV $(\%)$ & 8.77 & 10.79 & 10.75 & 37.25 & 35.27 & 37.23 & 17.80 \\
\hline Pr & 0.40 & 0.23 & 0.37 & 0.52 & 0.12 & 0.76 & 0.23 \\
\hline Notasi & tn & tn & tn & tn & tn & tn & tn \\
\hline
\end{tabular}

Keterangan: tn: tidak berbeda nyata pada taraf 5\%, BST: bulan setelah tanam, Pr: probabilitas, CV: Coefficient of Variance

\section{KESIMPULAN}

Tanah pada lokasi penelitian tergolong tanah liat dengan kandungan hara $\mathrm{C}$ dan $\mathrm{N}$ kategori sedang, Ca kateori rendah, dan $\mathrm{Mg}$ kategori tinggi. Pemupukan unsur Ca pada TBM-2 dosis $0 \mathrm{~g}$ $\operatorname{tanaman}^{-1} ; 600 \mathrm{~g} \mathrm{tanaman}^{-1} ; 1200 \mathrm{~g}$ tanaman $^{-1}$; dan $2400 \mathrm{~g}$ tanaman $^{-1}$ tidak memberikan pengaruh nyata pada tinggi tanaman, lingkar batang, jumlah pelepah tumbuh, panjang pelepah daun ke-9, dan luas daun. Pemberian pupuk kandang $50000 \mathrm{~g}$ lubang tanam $^{-1}$ tidak memberikan perbedaan pertumbuhan pada setiap perlakuan dan cukup 
sebagai pupuk sebelum penanaman. Kandungan hara pada jaringan diperoleh $\mathrm{N}$ dan $\mathrm{P}$ defisiensi, $\mathrm{K}$ optimum, dan $\mathrm{Ca}$ pada kategori antara optimum dan berlebih.

\section{DAFTAR PUSTAKA}

[BPS] Badan Pusat Statistik. 2011. Statistik Indonesia. Statistical Pocketbook of Indonesia 2011. (ID): BPS.

Buckman, H.O., Brady, N.C. 1982. Ilmu Tanah. Soegiman, penerjemah. Jakarta (ID): Bhratara Karya Aksara. Terjemah dari The Nature and Properties of Soils.

Campbell, N.A., Reece, J.B., Mitchell, L.G. 2008. Biologi. Wulandari, D.T., penerjemah. Jakarta (ID): Penerbit Erlangga. Terjemah dari: Biology.

[Ditjenbun] Direktorat Jenderal Perkebunan. 2011. Statistik Perkebunan Indonesia Kelapa Sawit 2010-2012.

Jakarta (ID): Ditjen Perkebunan.

Farhana, M.A., Yusop, M.R., Harun, M.H., Din, A.K. 2007. Performance of Tenera Population for The Chlorophyll Contens and Yield Component. Palm Oil Congress (Agriculture, Biotechnology \& Sustainability). (2007 Agustus 26-30); Malaysia.

Hartley, C.W.S. 1977. The Oil Palm (Elaeis guineensis Jacq.). New York (US): Longman Group Limited London.

Koedadiri, A.D., Darmosarkoro, W., Sutarta, E.S. 2007. Potensi dan pengelolaan tanah ultisol pada beberapa wilayah perkebunan kelapa sawit di Indonesia. Di dalam: Darmosarkoro, W., Sutarta, E.S., Winarna, editors. Lahan \& Pemupukan Kelapa Sawit. Edisi I. Medan (ID): Pusat Penelitian Kelapa Sawit. hlm. 1-24.

Mathius, N.T., Wijana, G., Guharja,E., Aswidinnoor, A., Yahya, S., Subronto. Respons tanaman kelapa sawit (Elaeis guineensis Jacq.) terhadap cekaman kekeringan. Menara Perkebunan 69(2): $29-45$.

Millar, C.E. 1955. Soil Fertility. New York (US): John Wiley \& Sons, Inc.
Munawar, A. 2011. Kesuburan Tanah dan Nutrisi Tanaman. Bogor (ID): IPB Press.

Ningsih, E.P. 2013. Optimasi pemupukan kalsium dan magnesium pada bibit kelapa sawit (Elaeis guineensis Jacq.) di pembibitan utama [tesis]. Bogor (ID): Institut Pertanian Bogor.

Pahan, I. 2013. Panduan Lengkap Kelapa Sawit. Jakarta (ID): Penebar Swadaya.

Rahutomo , S., Sutarta , E.S. 2007. Kendala budidaya kelapa sawit pada tanah sulfat masam. Di dalam: Darmosarkoro, W., Sutarta, E.S., Winarna, editors. Lahan \& Pemupukan Kelapa Sawit. Edisi I. Medan (ID): Pusat Penelitian Kelapa Sawit. hlm. 3543.

Sarief, E.S. 1985. Kesuburan dan Pemupukan Tanah Pertanian. Bandung (ID): Pustaka Buana.

Setiawan, Tohari, Shiddieq, D. 2013. Pengaruh cekaman kurang air terhadap beberapa karakter tanaman nilam (Pogostemon cablin Benth). J.Littri. 19 (3):108-116.

Siallagan, I., Sudradjat, Hariyadi. Optimasi dosis pupuk organik dan npk majemuk pada tanaman kelapa sawit belum menghasilkan. 2014. J. Agronomi Indonesia.42(2):166-172.

Sopandie, D. 2014. Fisiologi Adaptasi Tanaman terhadap Cekaman Abiotik pada Agroekosistem Tropika. Bogor (ID): IPB Press.

Sudradjat, Sukmawan, Y., Sugiyanta. Influence of manure, nitrogen, phosphorus and potassium fertilizer application on growth of one-yearold oil palms on marginal soil in Jonggol, Bogor, Indonesia.. 2014. Journal of Tropical Crop Science 1(2).

Sukmawan, Y. 2014. Peranan pupuk organik dan anorganik terhadap pertumbuhan kelapa sawit (Elaeis guineensis Jacq.) umur satu tahun pada tanah marginal [tesis]. Bogor (ID): Institut Pertanian Bogor. 
Sutarta, E.S., Rahutomo, S., Darmosarkoro, W., Winarna. 2007. Peranan unsur hara dan sumber unsur hara pada pemupukan tanaman kelapa sawit. Di dalam: Darmosarkoro, W., Sutarta, E.S., Winarna, editors. Lahan dan Pemupukan Kelapa Sawit. Edisi I. Medan (ID): Pusat Penelitian Kelapa Sawit. hlm. 7980.

Tisdale, S.L., Nelson, W.L., Beaton, J.D. 1990. Soil Fertility and Fertilizer Fourth Edition. New York (US): Macmillan Publishing Company.
Uexkull, H.R., Fairhurst, T.H., Mutert, E. 1992. Fertilizing for high yield and quality the oil palm dalam Fairhurst, T.H., Mutert, E. : Interpretation and management of oil palm leaf analysis data. Better Crops International.13(1).

Widodo, H.H. 2014. Peranan pupuk kalsium pada kelapa sawit (Elaeis guineensis Jacq.) belum menghasilkan umur 1 tahun (TBM1) [skripsi]. Bogor (ID): Institut Pertanian Bogor. 